\title{
SPATIAL ANALYSIS OF EROSION AND QUANTIFICATION OF SOIL LOSSES IN WESTERN ALGERIA
}

\author{
BENAMAR BELGHERBI $\bowtie$, KHELOUFI BENABDELI
}

Research Laboratory in Geo-Environment and Spaces Development, Faculty of Science of Nature and Life, University of Mascara. BP 305 Sidi Said University of Mascara 29000, Algeria; e-mail: benamar.belgherbi@univ-mascara.dz; benandeli_k@yahoo.fr

$\triangle$ Corresponding author

Received: 4 August 2019 / Accepted: 3 February 2020

\begin{abstract}
Belgherbi B., Benabdeli K.: Spatial analysis of erosion and quantification of soil losses in western Algeria. Ekológia (Bratislava), Vol. 40, No. 2, p. $130-136,2021$.

The objective of this study is to establish a soil loss map of a region located in western Algeria allowing the spatialization of erosion models, deposition, and quantification of soil loss. The model applied is Universal Soil Loss Equation (USLE), wich was developed by Wischmeier and Smith. The map of current soil losses derived from it shows five areas: very low, low, medium, strong, and very strong. The significant loss in soil areas is located in most of the south of the area, the upstream mountains part, and a portion to the northwest of the region. They cover an area of 16,805 ha ( $15.27 \%$ ) of the study area. The remainder of area constituting unrigged flat terrain accounts for a loss in low soil. The latter receives all the solid contributions which are deposited there constituting an important deposit.
\end{abstract}

Key words: USLE, erosion models, erosion factors, western Algeria, water erosion.

\section{Introduction}

Soil loss due to erosion is a global problem, especially affecting natural resources and agricultural production (Little Boy et al., 1992; Bakker et al., 2005; Pimentel, 2006; Parveen, Kumar, 2012; Ighodaro et al., 2013; Tung et al., 2018). Water erosion is a very widespread phenomenon in the world, and Algeria, like the other Maghreb countries, is among the regions most affected by this phenomenon. It becomes a complex and difficult phenomenon in Algeria where several factors contribute to it by intensifying it. This phenomenon has long been reported by several authors (Pouquet, 1952; Despois, 1956; Gréco, 1966; Benchetrit, 1972; Pouget, 1974; Sari, 1977; Néboit, 1983; Aubert, 1986; Mazour, Roose, 2002; Morseli et al., 2012; Meddi, 2015), highlighting that water erosion continues to degrade considerable proportions of soil, particularly in relief areas. It is the torrential nature of the rains and the combination of both natural and anthropogenic factors (inappropriate cultivation techniques, ploughing in the direction of slopes, degradation of perennial vegetation cover, fires, soil conditions, steep slopes, lack of vegetation cover, long periods of drought, fragile soils, and soft rocks) which accentuate the impact of this erosion on practically all productive spaces.

In Algeria, about 6 million hectares are exposed to active erosion. The average annual specific erosion varies between 2,000 and 4, $000 \mathrm{t} / \mathrm{km}^{2} /$ year; this figure makes Algeria a country most threatened by erosion in the world. An average of between 1 and
2 million $\mathrm{m}^{3}$ is the volume of sediment taken from the basin and deposited at sea for the only basin tributary to the Mediterranean. Demmak (1982), Combeau (1977) and Roose (1994) report that $45 \%$ of Algeria's surface area is affected by erosion, with 100 ha of arable land lost per rainy day and feeding the siltation of dams.

In Algeria, the adverse effects of erosion have resulted in a considerable loss of arable land, a disfigurement of the physical environment through landscape degradation, desertification of fragile natural environments, siltation of dams (example, Fergoug dam in the completely silted up study area), and the destruction of certain infrastructure such as roads and tracks.

The aim is to develop a methodology for estimating water erosion through quantification of soil losses resulting from groundwater erosion or gullies in Beni-Chougrane Mountains in western Algeria. The approach is based on identification and mapping of the different factors involved in the erosive process. It will be followed by a location of the areas likely to produce sediments, which will be quantified by integrating the Universal Soil Loss Equation (USLE) model established by Wischmeier and Smith (1978).

\section{Material and methods}

\section{Study area}

The study area is a depression surrounded by mountains and separated from the sea by dune cords. It is bounded to the 
north by the Arzew gulf and the coastal massifs, to the east by the southern part of the Mostaganem plateau, and to the south by the Beni-Chougrane Mountains (Fig. 1). It covers an area of $109,315 \mathrm{ha}$; the altitude is between 0 and $608 \mathrm{~m}$ (Fig. 2). It is part of the large catchment area called "Macta" covering an area of 1,368,677 ha. Due to its geographical position, the study area represents a downstream point in the watershed. The slopes of the study area varied from $0.5 \%$ to $25 \%$ (Fig. 3 ) and are fed by three wadis: Sig, Habra, and Tinn.

The geological formations consist of continental Quaternary terrain in a structure marked by drifts (Dalloni, 1919). From a bioclimatic point of view, it belongs to floor inferior with a temperate variant characterized by strong seasonal contrasts with brutal rains and concentrated between November and March (Belgherbi et al., 2018).

The dominant soils are salids (American soil classification) with the sodium ion in chloride state (Gaucher, Simmoneau, 1952; Tafer, 1993; Belgherbi, Benabdeli, 2016) and a low representation of young mountain soils and shell soils (Fig. 4).

The average population density is quite high approaching 78 inhabitants $/ \mathrm{km}^{2}$, with a dominant agricultural vocation since most of the slopes are exploited by rain cereal crops, which have aggravated erosion problems.

The study area can be divided into four entities:

- An agricultural entity represented by agricultural land located in the far south (citrus and olive orchards) and cereal fields both sides of the area.

- A forest entity represented by the Tamarix forest and a small Juniperus grove overlooking the coastal dune at a significant stage of degradation (Belgherbi, Benabdeli, 2010).

- A range entity consisting essentially of seasonal halophyte and hydrophytic plant species, annuals, and perennial species dominated by Salicornia, Arthrocnemum, Grasses, Rings, Isoetes, and Bolboschoenus maritimus (Quézel, Simmoneau, 1960).

- A seasonal marsh entity.

\section{Data and application model}

The adapted methodology consists of the application of the Universal Soil Loss Equation (USLE), revised according to Wischmeier and Smith (1978).

\section{Presentation of the model}

The Universal Soil Loss Equation groups all variables under five major factors (Wischmeier, Smith, 1978). It predicts the average soil loss in the field, losses that are caused by surface erosion (erosion by the impact of raindrops or beating, sheet erosion, and gully erosion). It is a multiplicative function of the five factors that control water erosion: climatic aggressiveness, soil erodibility, slope and length, land use, and erosion control practices. The formula is expressed:

$$
\mathrm{Ea}=\text { R. K. LS. C. P, }
$$

where Ea is average annual land losses ( $\mathrm{t} / \mathrm{ha} /$ year), $\mathrm{R}$ is rain erosion (climatic factor), $\mathrm{K}$ is soil erodibility factor, LS is topographic erosivity factor integrating slope and slope length, $\mathrm{C}$ is land cover factor, and $\mathrm{P}$ is agricultural practices factor.

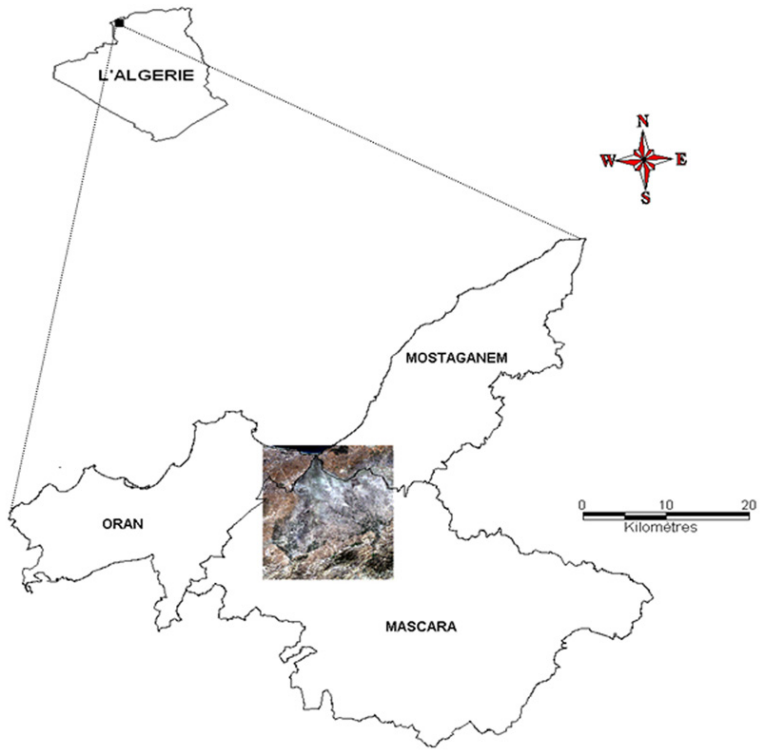

Fig. 1. Location of study area.

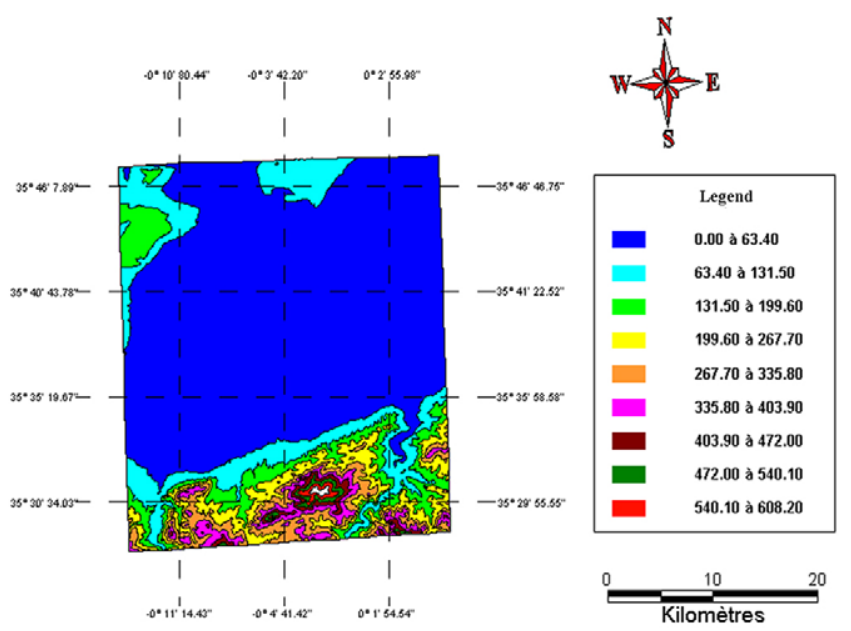

Fig. 2. Hypsometric map of study area.

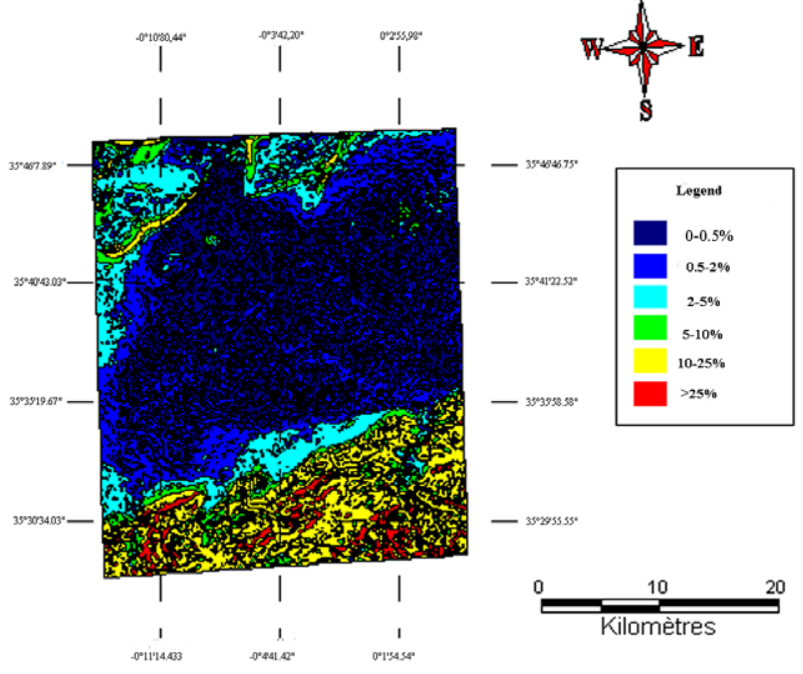

Fig. 3. Slope map of study area. 


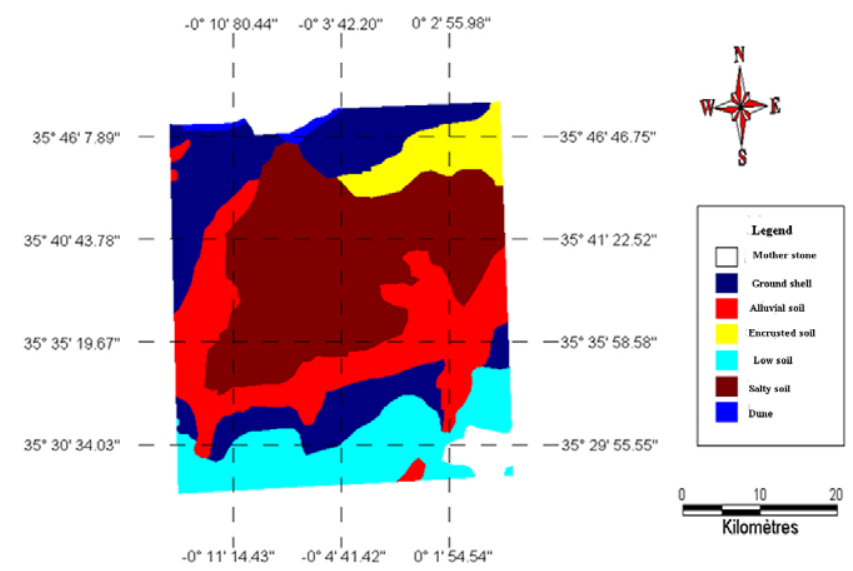

Fig. 4. Soil map of study area.

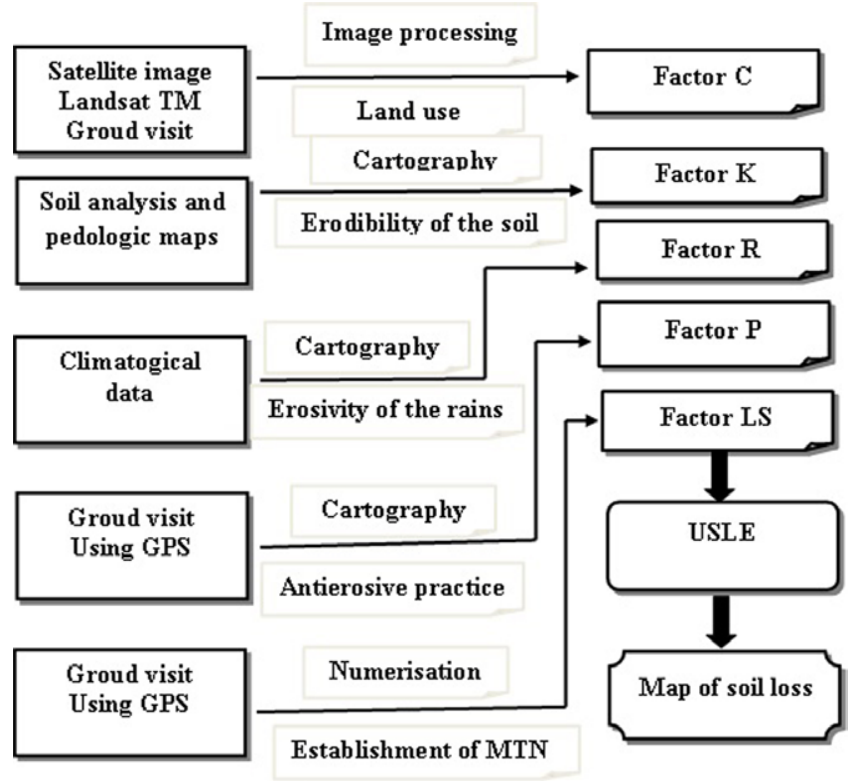

Fig. 5. Methodological flowchart.

The index rain erosivity ( $\mathrm{R}$ ) is equal to the kinetic energy of the rains, multiplied by the maximum rain intensity over 30 minutes expressed in $\mathrm{cm}$ per hour. The erosivity factor of rainfall (R) is a function of the falling raindrop and the rainfall intensity, and it is the product of kinetic energy of the raindrop and the 30-minute maximum rainfall intensity (Pandey et al., 2007). Some authors (Kalman, 1967; Arnoldus, 1980) have developed alternative formulas that only imply monthly and yearly precipitation. Rainfall erosion was calculated by applying the Arnoldus formula (Arnoldus, 1980). This choice depends on the nature of the precipitation data available at the reference meteorological station (Sidi Abdelmoumen station). The climatic aggressive factor $\mathrm{R}$ is expressed as follows:

$$
\mathrm{R}=1.735^{\star} 10^{\star}(1.50 \log \Sigma \mathrm{Pi} / \mathrm{P}-0.8188),
$$

where $\mathrm{I}$ is month and $\mathrm{P}$ is monthly precipitation.
The index soil erodibility $(\mathrm{K})$ was made by applying the Baril formula (Baril, 1988) tested in Mediterranean countries, notably in Greece, Spain, Tunisia, and Morocco, where it gave satisfactory results. $\mathrm{K}$ is strongly related to the physical proprieties of the soil and plays an important role in soil conservation strategies (Shabani et al., 2014). The $\mathrm{K}$ index is determined from the following expression:

$100 \mathrm{k}=2.1^{\star} 10-4^{\star}(12-\% \mathrm{MO}) \mathrm{M} 1.4+3.25^{\star}(\mathrm{S}-2)+2.5^{\star}(\mathrm{P}-3), \quad$ (3)

where $\mathrm{MO}$ is the percentage of organic matter, $\mathrm{S}$ is the structure code, $\mathrm{P}$ is the permeability class, and $\mathrm{M}$ is (\% fine sand $+\%$ silt) (100 - \% clay).

For spatialization of the $\mathrm{K}$ factor, several samples were taken from each soil type in study area. The analyses carried out concern grain size, organic matter content, and permeability. The results of the permeability obtained were attributed by a numerical value according to the classification of USDA (1952).

These data are entered into the USEL model, digitized in a GIS using the soil map of the study area, and assigned the respective erodibility factor $\mathrm{K}$ to each soil type. The index topographic factor (LS): Topographic factor is the slope length gradient factors comprising L, slope length, and S, slope steepness (Panagos et al., 2015). The LS index is determined from the following expression:

$$
\mathrm{LS}=(1 / 22,15) \mathrm{m}\left(65.41^{\star} \sin 2 S+4.56^{\star} \sin S+0.065\right),
$$

where $l$ is the length of the slope (in $\mathrm{m}$ ) and $\mathrm{S}$ is the slope inclination (in \%).

The LS topographic index is produced by juxtaposing two maps (slope map and slope length map). The vegetation cover factor (C) takes into account the nature and density of the vegetation cover. To be able to evaluate this factor for the different vegetation cover units, it is necessary to establish a land use map for our study area. The $\mathrm{C}$ factor is most important factor that controls soil erosion risk (Knijff et al., 2000). The results were compared with the study results of Cormary and Masson (1964) to assign a value to each plant formation represented at the study area level. The anti-erosion practices factor reflects techniques that reduce the amount of runoff and its velocity, thereby decreasing the effects of water erosion; such as: contour planting, shallow plowing, mulching,...

This index is estimated on the basis of field observations by evaluating the various actions taken to reduce the effect of erosion. This factor is obtained by comparison a standard $\mathrm{P}=1$ for unmanaged areas. If there is no erosion control solution, then $P$ value should be $1 . P$ is considered the most uncertain values (Morgan, Nearing, 2011).

\section{The data necessary for the application}

The data used can be summarized into two main categories: cartographic documents and satellite images. The various maps used to carry out this water erosion assessment work are six in number and are summarized in Table 1 . In the satellite image category, we have used Landsat TM image with a resolution of $30 \mathrm{~m}$. The choice of this type of satellite image was conditioned by both the presence of scenes containing the area and its availability has a resolution of $30 \mathrm{~m}$. 


\section{Methodology adopted}

The soil loss assessment was carried out using satellite images (Landsat TM), topographic maps at a scale of 1:50,000, the vegetation map of Santa et al. (1958), for a spatialized knowledge of erosion differentiation factors (land use, importance of vegetation cover) and measurements and observations of the ground. The use of Geographic Information System (GIS) for analysis and modeling of erosion and deposition processes will complement our approach. The approach adopted can be summarized as follows (Fig. 5):

- Several field trips were carried out to validate and correct the land use map, estimate and visualize erosion control techniques, and take soil samples for possible laboratory analysis.

- The satellite image was used to map land use and occupation in the region.

- The MapInfo 8.0 (GIS software) was manipulated to set up the digital terrain model (DTM) and obtain some maps, mainly the slope length map and the slope inclination map. The same software was used to create the soil map.

\section{Results}

\section{Determination of model parameters}

\section{Rainfall erosivity factor $(R)$}

The average annual rainfall from 1983 to 2017, provided by the Sidi Abdelmoumen station, was used to calculate the R factor for entire study area. The $\mathrm{R}$ value of $36.94 \mathrm{t} / \mathrm{ha} / \mathrm{h}$ was calculated on a single precipitation value $\mathrm{P}$ for an annual average precipitation of $243 \mathrm{~mm}$.

\section{Soil erodibility factor $(K)$}

Permeability analyses demonstrated two classes: a soil with a moderate water absorption rate and a slow to moderate soil, representing, respectively, according to the USDA classification (1951) a value of 3 and 4 .

The erodibility factor map (Fig. 6) thus established allowed to highlight five (5) classes taking into account the different types of soil encountered. The highest value is attributed to the shell soil, the inked soil, and the poorly evolved soil with $0.30,0.28$, and 0.21 , respectively. The values varied from 0.14 to the minimum and 0.30 to the maximum.

\section{Topographic factor (LS)}

The distribution map of the LS factor (Fig. 7) illustrates an important range in value where the index varies between 0.82 and 8.28. The highest values are located in the upstream part of the area; they are concentrated in the southern part of the area represented by a mountainous massif with steep slopes.

\section{Vegetation cover factor $(C)$}

The study area is mainly spatialized by three occupation classes and land use (Fig. 8): a first class represented by forest formations

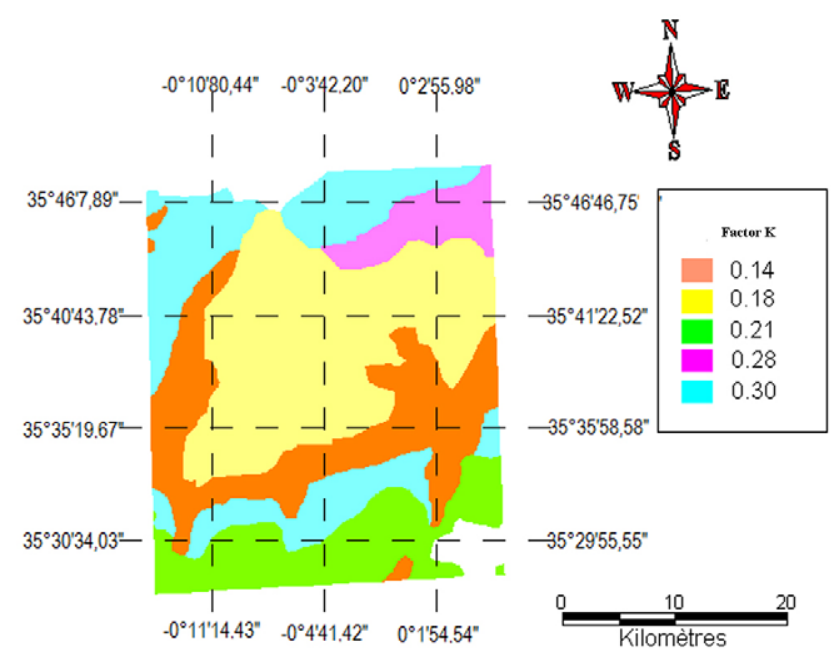

Fig. 6. Map of soil erodibility factor.

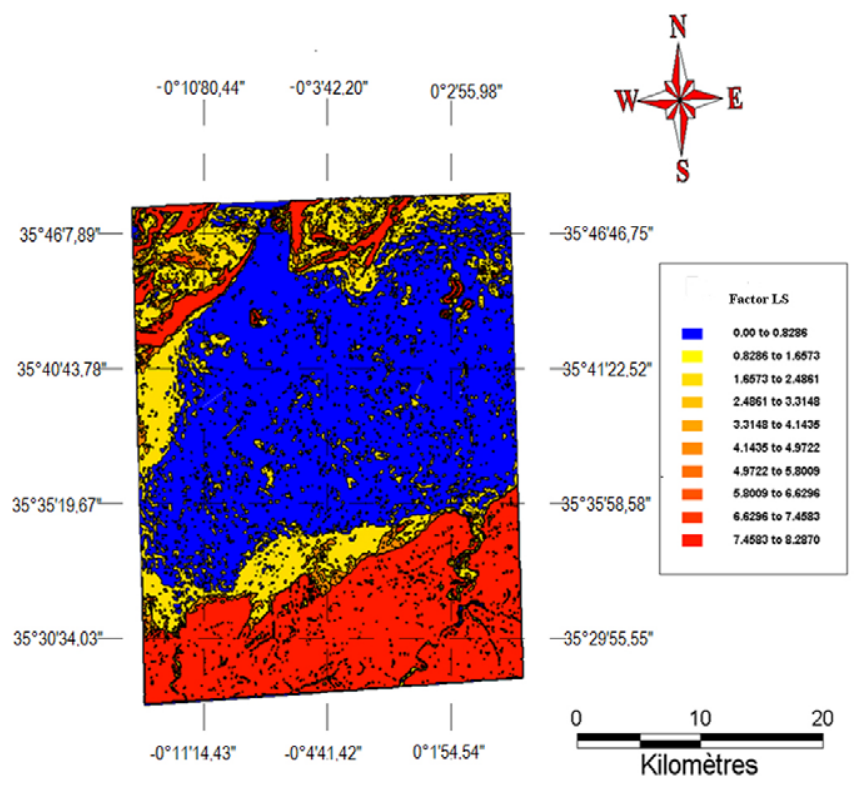

Fig. 7. Topographic factor map.

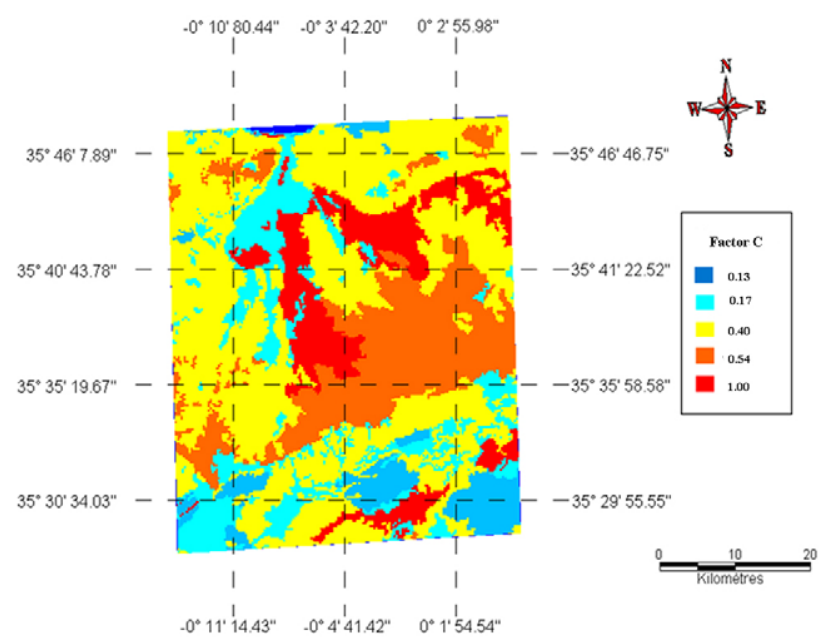

Fig. 8. Map of vegetation cover factor. 


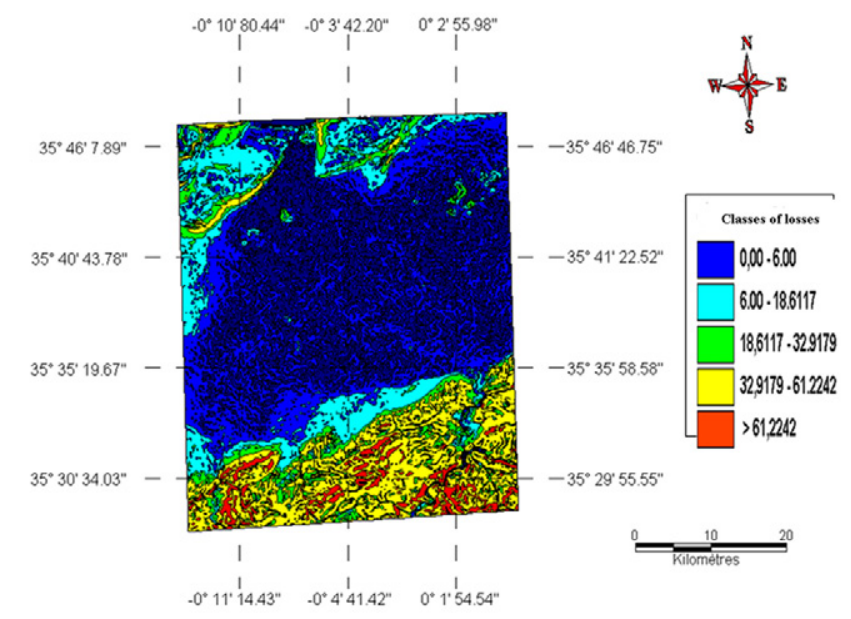

Fig. 9. Soil loss map.

totaling an area of 6,578 ha $(6.05 \%)$, a second class for agricultural and pastoral purposes covering 97,618 ha $(89.27 \%)$, and a last class covering bare soils, sebkha, and agglomerations with an area of 8,119 ha $(4.68 \%)$.

The values of the vegetation cover index vary between 0.13 and 1 depending on the type of land use where it is assigned to the bare soil the value 1 . The exploitation of map $n^{\circ} 8$ underlines that the value 0.40 represents cereal cultivation, class 0.13 represents grazing land, and class 1 represents bare soil.

\section{Anti-erosion practice factor $(P)$}

Agriculture practiced throughout the area is exclusively cerealbased; no application of anti-erosion cultivation techniques is practiced for the following reasons: land fragmentation, lack of resources, and ignorance of erosion problems. All interventions carried out on land with a steep tree slope, arboreal, reforestation, and cereal cultivation do not obey any rules taking into account the configuration of the land. No anti-erosion techniques are applied, such as low walls, bleachers, benches, and agricultural teenagers. In this context, the value $\mathrm{P}=1$ was assigned to the entire area of the study area.

\section{Erosion mapping and validation of results}

The combination of rain erosion factors $\mathrm{R}$, soil erosion $\mathrm{K}$, topographic factor LS, vegetation cover factor C, and practical anti-erosion factor P produced the soil loss map (Fig. 9). Slope, erodibility, and vegetation cover have greatly contributed to the development of soil map and soil behavior in the face of water erosion. As for the rain, it represents the engine of water erosion, but it remains less important than the factors mentioned above in classifying soils according to their sensitivity to water erosion.

The use of the soil loss map (Fig. 9) shows that soil losses vary between 6 and 61 . The most significant soil losses are located in the southern and northwestern part an area of 16,805 ha, representing a rate of $15.27 \%$ of the total area.

The moderate soil loss (6-18 t/ha/year) and low soil loss $(<6$ $\mathrm{t} /$ ha/year), respectively, affect 26,390 ha $(24.14 \%)$ and 66,220 ha $(60.57 \%)$ and are located in the central part of the area with an eastward enlargement.

\section{Discussion}

The value of erosivity factor remains very high considering that most of the rains are torrential and the study area remains bare for a fairly long period of the year on topography of an uneven terrain. According to Fournier (1960), solid transport was essentially a function of two factors: the topography and aggressiveness or continentality index of the rains.

The parameter erodibility factors show a clear fragility of soils and their susceptibility to erosion, knowing that the $\mathrm{K}$ index varies from 0.70 for most fragile soils to 0.01 on the most stable soils (Roose, 1994). The slope influences the aggressiveness of erosion, but the existence of erosion also on low slopes indicates that there is no need for a steep slope to trigger this phenomenon: rainfall action is sufficient (Fauck, 1956; Fournier, 1967).

The bare soil (vegetation cover factor) dominates more than $89 \%$ of the land occupation, which explains the area's vulnerability to erosion and the extent of land loss recorded. Late cultivated plots develop an erosion of less than $20 \%$ of the erosion measured on bare plots (Wischmeier, Smith, 1978). Mouffaddal (2002) confirms that groundwater erosion in forest environments, even degraded, and under olive trees remains modest despite the steep slopes. On fallow land, sediments are often trapped in tufts of grass, but runoff is abundant between tufts. The rangeland causes compaction of the superficial horizon and thus increases runoff, often resulting in gullying of downstream fields (Sabir et al., 1994).

Taking into account the tolerance threshold defined by Heusch (1982) as $12 \mathrm{t} / \mathrm{ha} /$ year, it appears that a fairly large part of the study area is subject to sheet erosion and intense runoff. The mountains part is characterized by uneven terrain and steep slopes. The soils are formed of particulate structure and granulometry predominantly so friable (young mountain soil and shell soil) and susceptible to erosion action. The widespread practice of cereal farming is another aggravating factor since the soil remains bare for more than 5 months, which generally corresponds to the autumn and winter rainy periods. In mountains, gully erosion and dry mechanical erosion processes are accentuated by steep slopes and quickly lead to the stripping of superficial horizons, most humiferous, especially when the soil is bare and worked on the surface by disc ploughing instruments.

The central part of the study area is represented by a very low-slope plain and alluvial saline soil, and it is a downstream point in the study area. It is also the place of deposition of the solid thrust produced by runoff and sheet erosion from the other part of the area. The highest soil losses and runoff occur at a time where the soil is already very humid and coincides with the stormy autumn and spring rains. It has been proven that sheet erosion selectively removes organic matter, clay silt colloids, and nutrients, while gutter erosion does not selectively scrape the soil. When gutter erosion develops, it generally decays the humus horizon, especially on steep slopes (Bolline, 1982).

But practically, as is the case in our study area, it is very difficult to separate sheet erosion from gully erosion (Fig. 4). Under such conditions, sloping terrain, from ground without vegetation cover for a significant period of the year and the presence of torrential rains, land losses are caused by sheet erosion due to the phenomenon of splash; it is the cause of the energy of rainfall beat on bare soils (Ellison, 1944). Subsequently, gully erosion takes place, giving rise to linear water erosion which can lead 
to widespread gullying or badlands. Several authors (Chaplot et al., 2004; Albergel et al., 2008; Benslimane et al., 2011) have confirmed that gully erosion produces significantly more erosion per hectare than sheet erosion. However, as this last affects much larger areas, it is sheet erosion that ultimately brings the most sediment to the dam.

The severity of the erosion problem and the importance of its impact on the land in the study area are not only due to physical factors (aggressive rainfall, slope length and slope, soil characteristics) but also largely responsible to anthropic factors (forest fires, trampling of livestock, illegal logging, cultural practices, speculation...) (Fig. 5). The results obtained confirm with a localized quantitative contribution that erosion in Algeria is at the origin of considerable land losses that also have negative impacts on the economy, such as infrastructure degradation and soil fertility.

\section{Conclusion}

The evaluation of soil losses undertaken in an area fairly representative of other regions of Algeria made it possible to highlight a classification of areas according to the size of the land losses recorded. The method used, based on the application of the Universal Soil Loss Equation (USLE) associated with remote sensing and geographic information system, made it possible to estimate the average loss of $55.22 \mathrm{t} / \mathrm{ha}$ /year. This value corresponds to very high erosion not tolerated by fragile soils, which are also subject to a semi-arid climate with low rainfall but stormy character.

Soil loss results valued up to $61.22 \mathrm{t} / \mathrm{ha} /$ year show that the southern and northwestern part of the study area is the most vulnerable; they are characterized by a dominance of shallow soils with a light texture and low organic matter content and located on high slopes. Approximately 16,805 ha $(15.27 \%)$ of the total area are concerned by this assessment. Regions of low soil loss or deposition correspond to areas of low slope located in the central part of the area that collects the erosion product (solid bedload) that constitutes a significant alluvial deposit.

\section{References}

Albergel, J., Zante, P., Collinet, J., Attiar, R. \& Merzouk A. (2008). Ravinement et bilan hydro-sédimentaire des lacs de retenue collinaires au Maghreb. In E. Roose, J. Albergel, G. de Noni, M. Sabir \& A. Laouina (Eds.), Efficacité de la GCES en milieux semi-arides (pp. 378-384). Paris: AUF, EAC, IRD.

Arnoldus, H.M.J. (1980). An approximation of the rainfall factor in the USLE. In M. de Boodt \& D. Gabriels (Eds.), Assessment of erosion (pp 127-132). New York: John Wiley.

Aubert, G. (1986). Réflexions sur l'utilisation de certains types de banquettes de "Défense et Restauration des Sols" en Algérie. Cahiers ORSTOM, série Pédologie, 22(2), 147-152.

Bakker, M.M., Govers, G., Kosmas, C., Vanacker, V., Oost, K.V. \& Rounse M. (2005). Soil erosion and drivers of land use change. Journal of Agriculture, Eco-Systems and Environment, 105, 467-481. DOI: 10.1016/j. agee.2004.07.009.

Baril, P. (1988). Notes de cours choisies sur lérosion el la conservation des sols. Ecole Polytechnique Fédérale de Lausanne.

Belgherbi, B. \& Benabdeli K. (2010). Contribution à l'étude des causes de dégradation de la forêt de Tamarix au niveau de la zone humide de la Macta (Algérie occidentale), Revue Forêt Méditerranéenne, 31(1), 55-62.

Belgherbi, B. \& Benabdeli K. (2016). Etude phyto-écologique et préservation de la biodiversité de la zone humide de la Macta (Algérie occidentale). Edition Universitaires Européennes.
Belgherbi, B., Benabdeli, K. \& Mostefai K. (2018). Mapping the risk of forest fires in Algeria: Application of the forest of Guetarnia in western Algeria Ekológia (Bratislava), 37(3), 289-300. DOI: 10.2478/eko-2018-0022.

Benchetrit, M. (1972). Lérosion actuelle et ses conséquences sur l’aménagement en Algérie. Édit. Presses Universitaires de France, Paris, PUF.

Benslimane, A., Raclot, D., Evrard, O., Sanaa, M., Lefevre, I., Ahmadi, M. \& Le Bissonnais Y. (2011). Quantification des sources d'érosion à l'échelle du bassin versant : illustration sur le bassin de Kamech, Cap Bon, Tunisie. Colloque sur lérosion hydrique et la vulnérabilité des sols au Maghreb : état des lieux et perspectives (Rabat).

Bolline, A. (1982). Etude et prévision de lérosion des sols limoneux cultivés en moyenne Belgique. Thèse Doctorat Géographie, Univ Liège (Belgique). IRSIA.

Chaplot, V., Le Bissonnais, Y., Bernadou, J. \& Runnoff (2004). Soil andSOC losses with a small sloping land catchment of Laos under shifting cultivation. Bulletin du Réseau Érosion, 22, 263-276.

Combeau, A. (1977). Erosion et conservation des sols. Paris: Cahiers ORSTOM.

Cormary, Y. \& Masson J. (1964). Application à un projet type de la formule de perte de sols de Wischmeier: étude de conservation des eaux et du sol. Cahiers ORSTOM, série Pédologie, 2(3), 3-26.

Dalloni, M. (1919). Le terrain houiller sur le littoral de la province d'Oran. Comptes Rendus de l'Académie des Sciences, 168, 1008-1010.

Demmak, A. (1982). Contribution à l'étude de lérosion et des transports solides en Algérie septentrionale. Thèse de Docteur Ingénieur, Université de Paris VI.

Despois, J. (1956). La culture en terrasses en Afrique du Nord. Annales Économie, Société et Civilisation, 11(1), 42-50.

Ellison, W. (1944). Studies of raindrop erosion. Agricultural Engineering, 25, 131-181.

Fauck, R. (1956). Erosion et mécanisation agricole en Casamance (Sénégal). Bureau du sol en Afrique occidentale.

Fournier, F. (1960). Climat et érosion. Presses Universitaire de France (PUF).

Fournier, F. (1967). La recherche en érosion et conservation des sols sur le continent africain. Sols Africains, 12(1), 5-53.

Gaucher, G. \& Simoneau P. (1952). Monographie agricole de la plaine de Saint Denis. Terres et Eaux, 14 et 15.

Gréco, J. (1966). L'érosion, la défense et la restauration des sols et le reboisement en Algérie. Alger: MARA.

Heusch, B. (1982). Etude de lérosion et des transports solides en zone semiaride. Recherche bibliographique sur l'Afrique du nord, Projet RAB, PNUD, 80-04.

Ighodaro, I.D., Lategan, F.S. \& Yusuf S.F.G. (2013). The impact of soil erosion on agricultural potential and performance of Sheshegu community farmers in the eastern cape of south Africa. J. Agric. Sci., 5(5), 140-147. DOI : $10.5539 /$ jas.v5n5p140.

Kalman, R. (1967). Le facteur climatique de l'érosion dans le bassin de Sebou (Maroc). Projet Sebou, Rapp inédit. Ministère de l'agriculture.

Knijff, J.M., Jones, R.J.A. \& Montanarella L. (2000). Soil erosion risk assessment in Europe. Joint Research Centre, European Commission, EUR $19044 \mathrm{EN}$.

Little Boy, M., Freebairn, D.M., Hammer, G.L. \& Silburn D.M. (1992). Impact of soil erosion on production in cropping systems. II. Simulation of production and erosion risks for a wheat cropping system. Aust. J. Soil Res., 30(5), 775-788. DOI: 10.1071/SR9920775.

Mazour, M. \& Roose E. (2002). Influence de la couverture végétale sur le ruissellement et l'érosion des sols sur parcelles d'érosion dans les bassins versants du Nord-ouest de l'Algérie. Bulletin du Réseau Érosion, 21, 320-330.

Meddi, M. (2015). Contribution à l'étude du transport solide en Algérie du nord. Larhyss Journal, 24, 315-336.

Morgan, R.P.C. \& Nearing M.A. (2011). Handbook of erosion modeling. Blackwell Publishing. DOI: 10.1002/9781444328455.

Morseli, B., Habi, M., Mazour, M., Hamoudi, A. \& Halitim A. (2012). Erosion et ruissellement en montagnes méditerranéennes d'Algérie du Nord: analyse des facteurs conditionnels sous pluies naturelles et artificielles. Revue Marocaine des Science Agronomiques et Vétérinaires, 1(1), 33-40.

Mouffaddal, K. (2002). Premiers résultats des parcelles d'érosion dans le bassin de Nakhla, Maroc. Bulletin du Réseau Érosion, 21, 244-254.

Néboit, R. (1983). L’homme et l'érosion : l'érosion des sols dans le monde. Association des publications de la faculté des lettres et des sciences humaines. France. 
Panagos, P., Borrelli, P. \& Meusburger K. (2015). A new european slope length andSteepnees factor (LS-factor) for modeling soil erosion by water. Geosciences, 5(2), 117-126. DOI: 10.3390/geosciences5020117.

Pandey, A., Chowdary, V.M. \& Mal B.C. (2007). Identification of critical erosion prone area in the small agricultural watershed using USLE, GIS and remote sensing. Water Resources Management, 21(4), 729-746. DOI 10.1007/s11269-006-9061-z.

Parveen, R. \& Kumar U. (2012). Integrated approach of universal soil loss equation (USLE) and geographical information system (GIS) for soil loss risk assessment in upper south Koel Basin, Jharkhand. Journal of Geographic Information System, 4(6), 588-596. DOI: 10.4236/ jgis.2012.46061.

Pimentel, D. (2006). Soil erosion: A food and environmental threat. Environment, Development and Sustainability, 8(1), 119-137. DOI : 10.1007/ s10668-005-1262-8.

Pouget, M. (1974). Etude agro-pédologique de la région d’Ouzera (Algérie). Rapport ANRH, Alger.

Pouquet, J. (1952). Les Monts du Tessala (chaînes sud-telliennes d'Oranie) Essai morphogénétique. Revue de Géographie Alpine, 40(4), 691-694.

Quezel, P. \& Simmoneau P. (1960). Quelques aspects de la végétation des terrains salés des plaines sub-littorales de l'Oranie orientale. DHER, Bull, $\mathrm{n}^{\circ} 6$, Alger.
Roose, E. (1994). Introduction à la gestion conservatoire de l'eau, de la biomasse et de la fertilité des sols (GCES).FAO Soils Bulletin Vol. 70. Rome.

Sabir, M., Merzouk, A. \& Berkat O. (1994). Impact du pâturage sur les propriétés hydriques du sol dans un milieu pastoral aride : Maroc. Bulletin du Réseau Érosion, 14, 444-462.

Santa, S., Daumas, P., Simonneau, P., Chavassut, G.\& Jacquard B. (1958) Carte de la végétation de l'Algérie. Bosquet-Mostaganem.

Sari, D. (1977). L'homme et l'érosion dans l'Ouarsenis (Algérie). Alger: SNED.

Shabani, F., Kumar, L. \& Esmaeili A. (2014). Improvement to the prediction of the USLE K factor. Geomorphology, 204, 229-234. DOI: 10.1016/j.geomorph.2013.08.008.

Tafer, B. (1993). Etude phytoécologique des complexes de végétation halophiles de la plaine de Mohammadia (Macta-Oranie). Thèse Doc, Université de Droit, d'économie et des sciences d'Aix-Marseille.

Tung, G.P., Jan, D. \& Martin K. (2018). Integrated universal soil loss equation (USLE) and Geographical Information System (GIS) for soil erosion estimation in ASap basin: Central Vietnam. International Soil and Water Conservation Research, 6, 99-110. DOI: 101016/j.iswcr.2018.01.001.

USDA (1951). Soil survey manual. Washington: USDA.

Wischmeier, W. \& Smith D. (1978). Predicting rainfail erosion losses - A guide to conservation planning. Washington: USDA. 